\title{
SCIENCE EDUCATION'S DIDACTIC TEST OF THE THEME TECHNIQUE AND TECHNICAL DISCOVERIES
}

\section{Ivana KRUPOVÁ}

\begin{abstract}
In the article we present suggesting Science education's didactic test of theme Technique and technic discoveries which is not focused on investigating of capacity of acquired knowledge but on investigating of level of scientific literacy. Solving of didactic test's tasks require deeper conceptual understanding and abilities of using knowledge on solving problem tasks from real life pupils.
\end{abstract}

Key words: didactic test, Science education, Technique and technical discoveries, primary education.

\section{DIDAKTICKÝ TEST Z PRÍRODOVEDY PRE TEMATICKÝ CELOK TECHNIKA, TECHNICKÉ OBJAVY}

Resumé: V príspevku uvádzame navrhovaný didaktický test z prírodovedy pre tematický celok Technika, technické objavy, ktorý sa nezameriava na zistovanie objemu osvojených vedomostí, ale na zistovanie úrovne prírodovednej gramotnosti. Vyriešenie úloh didaktického testu vyžaduje od žiakov hlbšieho pochopenie pojmov a schopnosti využivat' nadobudnuté vedomosti na riešenie problémových úloh z bežného života.

Klíčová slova: didaktický test, prírodoveda, Technika, technické objavy, primárne vzdelávanie.

Úvod

Význam hodnotenia a klasifikácie ako neoddelitel'nej súčasti edukačného procesu nie je potrebné osobitne zdôrazňovat'. Každý učitel' si je vedomý zložitosti a náročnosti tohto procesu. Podklady na hodnotenie a klasifikáciu žiaka môže učitel' získat' jeho sústavným diagnostickým pozorovaním, sledovaním jeho výkonu a pripravenosti na vyučovanie, rôznymi druhmi písomných, ústnych alebo praktických skúšok, analýzou výsledkov činností, konzultáciou s ostatnými učitel'mi (príp. inými odborníkmi), rozhovormi s rodičmi alebo samotným žiakom. Medzi efektívne prostriedky merania školskej úspešnosti žiakov patrí didaktický test. Naším zámerom bolo vytvorit' didaktický test pre tematický celok Technika, technické objavy z prírodovedy, ktorý by čo najobjektívnejšie zist'oval úroveň poňatia učiva žiakmi. Test je zostavený tak, že s malými obmenami môže byt' využitý ako vstupný aj výstupný test $\mathrm{k}$ danej téme, aby jeho výsledky vystihovali posun vo výkone každého žiaka.

Podl'a I. Tureka (1996) možno vytvorený didaktický test na základe viacerých kritérií označit' ako neštandardizovaný, kognitívny, vstupný a výstupný, subjektívne skórovatel'ný, monotematický, rozlišujúci (test relatívneho výkonu).

Tab. 1: Zastúpenie úloh z učiva Technika, technické objavy $v$ didaktickom teste.

\begin{tabular}{|c|c|c|c|c|c|c|c|c|}
\hline \multirow{3}{*}{$\begin{array}{l}\text { OBSAH } \\
\text { Technika, tech. objavy }\end{array}$} & \multicolumn{4}{|c|}{ počet } & \multicolumn{4}{|c|}{$\begin{array}{l}\text { úroveň } \\
\text { osvojenia }^{1}\end{array}$} \\
\hline & \multicolumn{2}{|c|}{ hodín } & \multicolumn{2}{|r|}{ úloh } & $\mathrm{A}$ & B & $\mathrm{C}$ & $\mathrm{D}$ \\
\hline & 7 & $100 \%$ & 12 & $100 \%$ & - & 4 & 5 & 3 \\
\hline jednoduché stroje & 3 & 42,86 & 5 & 41,67 & - & 1 & 2 & 2 \\
\hline elektrický obvod & 1 & 14,29 & 1 & 8,33 & - & 1 & - & - \\
\hline elektrická vodivost' & 2 & 28,57 & 4 & 33,33 & - & - & 3 & 1 \\
\hline $\begin{array}{l}\text { el. energia (výroba, } \\
\text { spotreba, } \\
\text { bezpečnost') }\end{array}$ & 1 & 14,29 & 2 & 16,66 & - & 2 & - & - \\
\hline
\end{tabular}

Test obsahuje 12 úloh, ktoré sú charakterizované v1. kapitole. V tabul'ke 1 uvádzame pri každej úlohe typ a zaradenie

\footnotetext{
${ }^{1}$ Niemierkova taxonómia vzdelávacích ciel’ov:

A - zapamätanie poznatkov (schopnost' vybavit' si určité fakty, pričom ich nesmie navzájom zamieňat');

B - porozumenie poznatkov (schopnost' predložit' zapamätané poznatky $\mathrm{v}$ inej forme než v tej, $\mathrm{v}$ ktorej si ich zapamätal); $\mathrm{C}$ - používanie vedomostí v typových situáciách (schopnost' použit' vedomosti k riešeniu situácií, ktoré už boli riešené);

D - používanie vedomostí v problémových situáciách (schopnost' použit' vedomosti k riešeniu situácií, ktoré ešte neboli riešené).
} 
do klasifikácie podl’a B. Niemierka (1979). Našim zámerom bolo vytvorit' úlohy, ktoré by boli vhodné pri diagnostikovaní žiakovho poňatia učiva - J. Čáp a J. Mareš (2001) uvádzajú, napr. analýzu žiackych výkonov a výtvorov, detskej kresby, široké úlohy v didaktických testoch (neštruktúrované, štruktúrované, produkčné).

\section{Charakteristika úloh didaktického testu}

Vyriešením úloh v didaktickom teste by mali žiaci preukázat', či si osvojili náročnejšie pojmy, či sú schopní posúdit' aj situácie, v ktorých je možné využit' osvojené prírodovedné vedomosti.

\section{Ku každému pojmu napíš, čo podl’a teba znamená. (pretest) /Ku každému pojmu napíš všetko, čo o ňom vieš. (posttest)
a) PÁKA
b) KLADKA
c) NAKLONENÁ ROVINA

- otvorená úloha so stručnou odpoved’ou, produkčná;

- úloha vyžadujúca porozumenie poznatkov.

Slovné vyjadrenie pojmov $\mathrm{v}$ úlohe bolo vyhodnocované spoločne s grafickým náčrtom $\mathrm{v}$ úlohe 2 .

\section{Nakresli ako l'udia využívajú:}

\section{a) PÁKU \\ b) KLADKU \\ c) NAKLONENÚ ROVINU}

- grafická úloha vyžadujúca jednoduchý náčrt';

- úloha vyžadujúca porozumenie poznatkov.

Za každú úspešne vyriešenú dvojicu úloh $1 \mathrm{a}+2 \mathrm{a}, 1 \mathrm{~b}+2 \mathrm{~b}, 1 \mathrm{c}+2 \mathrm{c}$ sme pridelili maximálne 3 body (spolu 9 bodov). V prvej úlohe sme za úplnú správnu odpoved' ( 3 body) považovali, ak žiak uviedol generalizáciu, napr. že je to pomôcka pri zdvíhaní alebo premiestňovaní predmetov a správne uviedol alebo nakreslil príklad využívania spomínaných jednoduchých strojov. Za neúplnú odpoved' mohol žiak získat' 2 body, ak uviedol, že je to pomôcka na zdvíhanie či premiestňovanie predmetov, a 1 bod, ak uviedol aspoň jeden konkrétny príklad

\footnotetext{
${ }^{2}$ Pri vyhodnocovaní grafických úloh sme sa zameriavali na to, či žiak dokáže zvýraznit' podstatné znaky, pričom nesúvisiace detaily neberie do úvahy a nezvýrazňuje. Nehodnotili sme úroveň samotnej detskej kresby, ale schopnost' rozlísit' to, čo je podstatné pre pochopenie javu.
}

využitia daného jednoduchého stroja. Body za dvojicu úloh boli pridel'ované komplexne, pretože sme prihliadali aj na to, ktorú formu vyjadrenia vlastných myšlienok (textovú alebo grafickú) žiaci preferujú. Napr. ak žiak správne charakterizoval pojem a uviedol aspoň 1 príklad praktického využitia, pridelili sme mu 3 body. A naopak, ak žiak uviedol neúplnú charakteristiku pojmu (napr. len príklad jeho praktického využitia), ale jeho kresba výstižne vyjadrovala využitie jednoduchého stoja na ul'ahčenie práce pri zdvíhaní predmetov, pridelili sme mu 3 body.

\section{Napíš aspoň 5 činností, ktoré nemôžeš robit' bez elektrickej energie.}

- otvorená úloha so stručnou odpoved'ou, produkčná;

- úloha vyžadujúca používanie vedomostí $\mathrm{v}$ typových situáciách.

Ak žiak uviedol 5 činností, resp. 5 elektrospotrebičov, ktoré nie je možné využívat' bez elektrickej energie, pridelili sme mu 1 bod.

\section{Ku každému pojmu napíš, čo podl'a teba} znamená. (pretest) /Ku každému pojmu napíš všetko, čo o ňom vieš. (posttest)
a) ELEKTRICKÁ ENERGIA
b) ELEKTRICKÝ OBVOD
c) ELEKTRICKÝ SPOTREBIČ

- otvorená úloha so stručnou odpoved'ou, produkčná;

úloha vyžadujúca porozumenie poznatkov.

$\mathrm{Za}$ správne vyriešenie úlohy mohol žiak získat' 6 bodov. Ak žiak uviedol, na čo sa využíva elektrická energia, a zároveň odkial' sa získava, resp. premenou ktorej energie vzniká, pridelili sme mu 2 body. Ak žiak uviedol, na čo sa využíva elektrický obvod a zároveň správne vymenoval jeho súčasti, pridelili sme mu 2 body. Ak žiak uviedol, že elektrické spotrebiče potrebujú na svoje fungovanie elektrickú energiu a uviedol aspoň jeden konkrétny príklad, pridelili sme mu 2 body. Za každú čiastočnú správnu odpoved' mohol žiak získat' 1 bod.

\section{Nakresli alebo napíš, ako l'udia využívajú} elektrickú energiu.

grafická úloha vyžadujúca jednoduchý náčrt; úloha vyžadujúca používanie vedomostí v typových situáciách. 
Za akúkol’vek kresbu, ktorá zobrazovala využívanie elektrickej energie l'ud'mi (napr. kresbu elektrického spotrebiča), sme pridelili 1 bod.

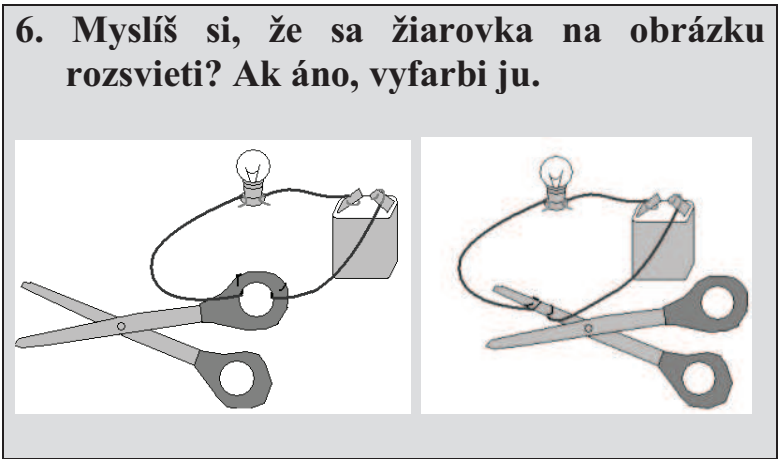

- uzavretá úloha s výberom odpovede;

- úloha vyžadujúca používanie vedomostí v typových situáciách.

Ak žiak vyfarbil žiarovku na obrázku, v ktorom je do elektrického obvodu zapojená kovová čast' nožníc (obrázok vpravo), získal 1 bod, v opačnom prípade mu nebol pridelený žiadny bod.

\section{Co by sme mohli zapojit' namiesto nožníc, aby žiarovka svietila?}

- otvorená úloha produkčná;

- úloha vyžadujúca používanie vedomostí v typových situáciách

Ak žiak uviedol tri predmety vyrobené z elektricky vodivého materiálu, prípadne uviedol elektricky vodivý materiál (napr. kov), pridelili sme mu 2 body. Ak uviedol aspoň jeden príklad elektrického vodiča, pridelili sme mu jeden bod. V prípade, že žiak uviedol jednu správnu a dve nesprávne odpovede, nepridelili sme mu žiadny bod, v prípade dvoch správnych a jednej nesprávnej odpovede sme pridelili jeden bod. Za správnu odpoved' sme považovali aj ,„̌iiarovku“, „vodič“”, „spínač“ ako súčasti elektrického obvodu, ktorými prechádza elektrický prúd.

\section{8. Čo by sme mohli zapojit' namiesto nožníc,} aby žiarovka nesvietila?

- otvorená úloha produkčná;

- úloha vyžadujúca používanie vedomostí v typových situáciách.

Ak žiak uviedol tri predmety vyrobené z elektricky nevodivého materiálu, prípadne uviedol elektricky nevodivý materiál (napr. plast, sklo), pridelili sme mu 2 body. Ak uviedol aspoň jeden príklad elektrického izolantu, pridelili sme mu jeden bod. (ostatné prípady boli hodnotené rovnako ako v úlohe 7 , napr. za správnu odpoved' sa považoval aj „otvorený spínač“..).

9. Predstav si, že sa vám doma pokazilo elektrické vedenie a ocko ho chce opravit'. Nevie však nájst' kombinačky, preto t’a poslal do obchodu kúpit' nové. Majú kombinačky s kovovou rúčkou za 25 Sk a kombinačky s plastovou rúčkou za 50 Sk. Ktoré by ste mu kúpili a prečo?

- otvorená úloha produkčná;

- úloha vyžadujúca použivanie vedomostí v problémových situáciách.

Ak žiak uviedol, že by kúpil kombinačky s plastovou rúčkou a svoju odpoved' správne zdôvodnil, pridelili sme mu dva body. Za správne vysvetlenia sme považovali, napr. plast je elektrický izolant (nevodič); ak by použil kovové kombinačky, mohol by ho zasiahnut' elektrický prúd a pod. (so zhovievavejším prístupom $\mathrm{k}$ formulácii žiackych vyjadrení, napr. „S plastovými, lebo s kovovými by ho mohlo pokopat"“, sme takúto formuláciu uznali ako správu odpoved' aj vysvetlenie). Ak žiak neuviedol zdôvodnenie svojej odpovede, nepridelili sme mu žiadny bod, čím sme zabránili, aby žiak získal body hádaním.

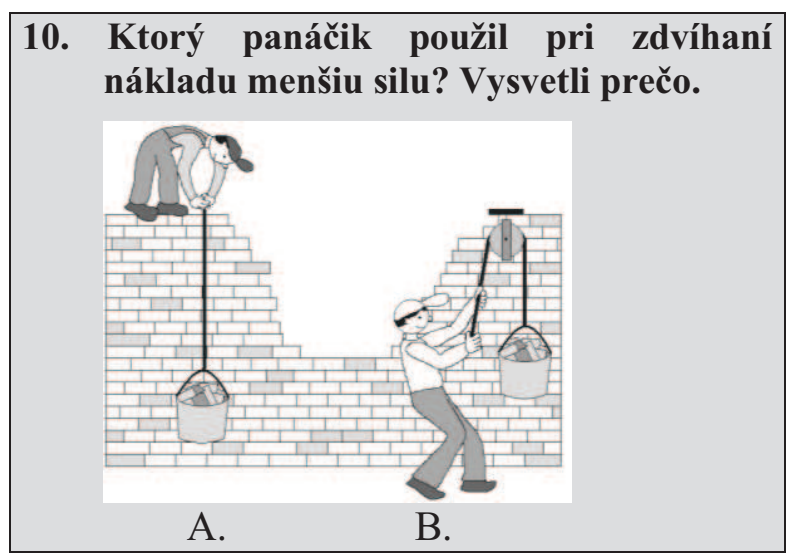

otvorená úloha produkčná;

úloha vyžadujúca používanie vedomostí v problémových situáciách.

Za správnu odpoved' a správne zdôvodnenie mohol žiak získat' spolu dva body. Za správnu odpoved' sme považovali, že obaja panáčikovia používajú rovnakú silu pri zdvíhaní nákladu a za 
správne zdôvodnenie, že pevná kladka nešetrí silu, len mení smer zdvíhania. Ak žiak neuviedol zdôvodnenie svojej odpovede, nezískal žiadny bod.

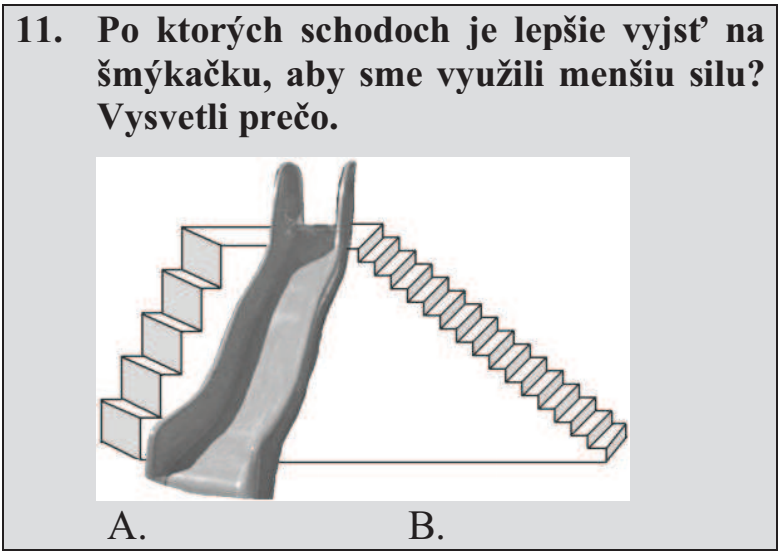

- otvorená úloha produkčná;

- úloha vyžadujúca používanie vedomostí v problémových situáciách.

Za správnu odpoved' a správne zdôvodnenie mohol žiak získat' dva body. Za správnu odpoved' sme považovali, že menšiu silu vynaložíme pri výstupe po schodoch $\mathrm{B}$ a za správne zdôvodnenie, že schody sú naklonená rovina a čím je naklonená rovina dlhšia, prípadne menej strmá, tým menšiu silu použijeme pri výstupe po nej. K žiackym odpovediam sme pristupovali zhovievavejšie a za správne vysvetlenia sme považovali, napr. „menej sa unavíme“, „,sú menej strmé“ a pod. Ak žiak neuviedol žiadne zdôvodnenie svojej odpovede, nezískal ani jeden bod.

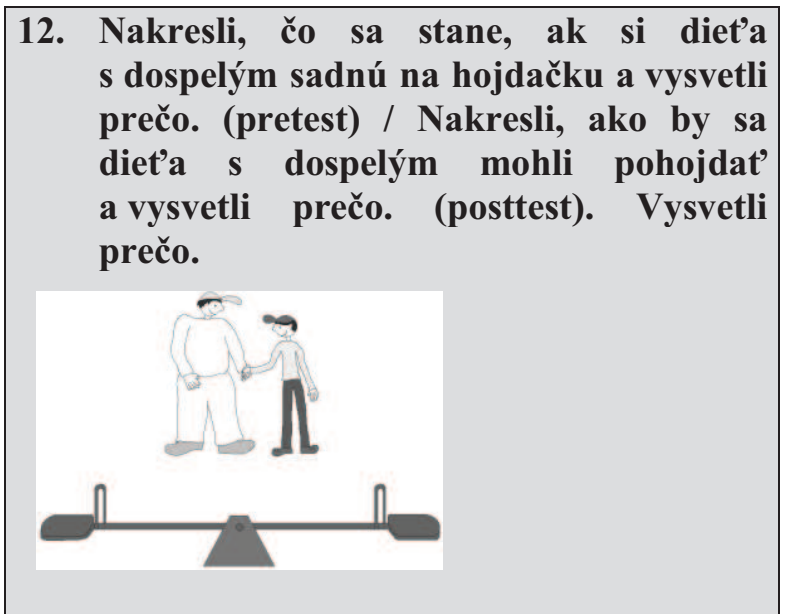

- otvorená úloha produkčná;

- úloha vyžadujúca používanie vedomostí v problémových situáciách.
Za správnu odpoved' a správne zdôvodnenie mohol žiak získat' dva body. Za správnu odpoved' sme považovali, že menšiu silu vynaložíme pri výstupe po schodoch $\mathrm{B}$ a za správne zdôvodnenie, že schody sú naklonená rovina a čím je naklonená rovina dlhšia, prípadne menej strmá, tým menšiu silu použijeme pri výstupe po nej. K žiackym odpovediam sme pristupovali zhovievavejšie a za správne vysvetlenia sme považovali, napr. „menej sa unavíme“, „sú menej strmé“ a pod. Ak žiak neuviedol žiadne zdôvodnenie svojej odpovede, nezískal ani jeden bod.

\section{Reliabilita a validita didaktického testu}

Pri zostavovaní didaktického testu je dôležité zabezpečenie jeho reliability - presnosti merania kognitívnej úrovne poňatia učiva žiakmi. M. Chráska (1999) uvádza, že čím viac úloh didaktický test obsahuje, tým vyššia je jeho reliabilita, preto by mal obsahovat' dostatočný počet úloh - najmenej 10. Vytvorený didaktický test obsahoval 12 úloh, pričom každá z úloh 1,2 , 4 obsahovala 3 podúlohy (a, b, c). Koeficientom reliability (r), ako ho uvádza R. Bernátová (2003), sme posudzovali, do akej miery sú výsledky nášho testovania ovplyvnené náhodou. Koeficient reliability sme vypočítali podla Cronbachovho vzt'ahu ${ }^{3}$ :

$$
\begin{aligned}
& r=\frac{m}{m-1} \cdot\left\{1-\frac{\sum s^{2} j}{s^{2}}\right\}= \\
& =\frac{15}{15-1} \cdot\left\{1-\frac{0,238}{30,96}\right\}=0,82
\end{aligned}
$$

Výsledok 0,82 spĺn̆a podmienku reliability ( $r$ by mal byt' väčší ako 0,6 ; čím viac sa približuje $\mathrm{k}$ hodnote 1 , tým je didaktický test reliabilnejší).

Z dôvodu zaistenia čo najvyššej možnej obsahovej validity testu, ktorá podl'a M. Lapitku (1996) spočíva vo výbere takých prvkov učiva, ktoré ho budú môct' reprezentovat' ako štruktúrny celok, sme sa usilovali vytvorit' úlohy pokrývajúce rovnomerne celé učivo. Naším zámerom pri tvorbe didaktického testu bolo, aby obsah testu reprezentoval učivo tematického

${ }^{3}$ kde za $m$ sme dosadili počet úloh v teste (pričom sme brali do úvahy počet všetkých úloh, vrátane čiastkových), za $s^{2}$ sme dosadili rozptyl skóre didaktického testu a za $s_{j}^{2}$ rozptyl skóre j-tej úlohy didaktického testu. 
celku Technika, technické objavy, aby sa $\mathrm{v}$ ňom nachádzali všetky dôležité časti učiva (bližšie v tabul'ke 1), pričom sme sa orientovali najmä na diagnostikovanie úrovne pochopenia pojmov a ich praktickej aplikácie pri riešení typických aj problémových úloh z bežného života.

Pri skórovaní jednotlivých úloh sme využili vážené skóre - každej úlohe sme pridelili váhu podl'a úrovne osvojenia. Úlohy na porozumenie poznatkov boli prevažne hodnotené jedným bodom, úlohy na používanie vedomostí $\mathrm{v}$ typových a problémových situáciách dvoma bodmi. V teste sa nenachádzali úlohy na zapamätanie poznatkov, pretože sme chceli predíst' tomu, aby žiaci získali body za mechanicky zapamätané poznatky. Usilovali sme sa o zist'ovanie pochopenia prírodovedných pojmov, pričom na vyriešenie úloh zameraných na porozumenie poznatkov a ich používanie v typových aj problémových situáciách sa už predpokladá ich zapamätanie. Celkové skóre didaktického testu bolo 30 bodov (tab. 2).

Tabul'ka 2: Skóre úloh v didaktickom teste.

\begin{tabular}{|c|c|c|c|c|c|c|c|c|}
\hline \multirow[b]{2}{*}{$\frac{\text { 플 }}{\frac{0}{\exists}}$} & \multicolumn{3}{|c|}{$1+2$} & \multirow[b]{2}{*}{3} & \multicolumn{3}{|c|}{4} & \multirow[b]{2}{*}{5} \\
\hline & $\begin{array}{c}1 \mathrm{a} \\
+2 \mathrm{a}\end{array}$ & $\begin{array}{c}1 \mathrm{~b} \\
+2 \mathrm{~b}\end{array}$ & $\begin{array}{c}1 \mathrm{c} \\
+2 \mathrm{c}\end{array}$ & & $4 a$ & $4 b$ & $4 c$ & \\
\hline \multirow{2}{*}{$\begin{array}{l}3 \\
0 \\
0\end{array}$} & 3 & 3 & 3 & 1 & 2 & 2 & 2 & 1 \\
\hline & 0,1 & 0,1 & 0,1 & 0,3 & 0,67 & 0,67 & 0,67 & 0,3 \\
\hline$\frac{\frac{\pi}{0}}{\frac{\partial}{0}}$ & 6 & 7 & 8 & 9 & 10 & 11 & 12 & \\
\hline \multirow{2}{*}{ : } & 1 & 2 & 2 & 2 & 2 & 2 & 2 & 30 \\
\hline & 0,33 & 0,67 & 0,67 & 0,67 & 0,67 & 0,67 & 0,67 & \\
\hline
\end{tabular}

Tabul'ka 3: Obtiažnost' úloh v didaktickom teste.

\begin{tabular}{|c|c|c|c|c|c|c|c|c|}
\hline \multirow[t]{2}{*}{ úloha } & \multicolumn{3}{|l|}{$1+2$} & \multirow[b]{2}{*}{3} & \multicolumn{3}{|l|}{4} & \multirow[b]{2}{*}{5} \\
\hline & $1 a+2 a$ & $1 b+2 b$ & $1 c+2 c$ & & $4 a$ & $4 b$ & $4 c$ & \\
\hline$n_{n}$ & 34 & 53 & 40 & 112 & 129 & 154 & 115 & 74 \\
\hline$n_{s}$ & 92 & 108 & 91 & 209 & 31 & 114 & 31 & 247 \\
\hline n & 321 & 321 & 321 & 321 & 321 & 321 & 321 & 321 \\
\hline $\bar{Q}$ & 11 & 17 & 12 & 35 & 40 & \begin{tabular}{|l|}
48 \\
\end{tabular} & 36 & 23 \\
\hline $\mathbf{P}$ & 29 & 34 & 28 & 65 & 10 & 36 & 10 & 77 \\
\hline úloha & 6 & 7 & 8 & 9 & 10 & \begin{tabular}{|l|}
11 \\
\end{tabular} & 12 & \\
\hline$n_{n}$ & 48 & 47 & 45 & 206 & 321 & 219 & 213 & \\
\hline$n_{s}$ & 273 & 188 & 232 & 116 & 0 & 103 & 1 & \\
\hline n & 321 & 321 & 321 & 321 & 321 & 321 & 321 & \\
\hline $\mathbf{Q}$ & 15 & 15 & 14 & 64 & 100 & 68 & 66 & \\
\hline $\mathbf{P}$ & 85 & 59 & 72 & 36 & 0 & 32 & 0 & \\
\hline
\end{tabular}

Za vel'mi náročnú možno považovat' úlohu 10 $(\mathrm{Q}=100, \mathrm{P}=0)$, za vel'mi jednoduché úlohy $1 \mathrm{a}+2 \mathrm{a}(\mathrm{Q}=11), 1 \mathrm{c}+2 \mathrm{c}(\mathrm{Q}=12), 8(\mathrm{Q}=14), 6(\mathrm{Q}$ $=15), 7(\mathrm{Q}=15), 1 \mathrm{~b}+2 \mathrm{~b}(\mathrm{Q}=17)$. Aj ked' sa odporúča úlohy, ktorých $\mathrm{Q}=100 \mathrm{z}$ testu vylúčit', rozhodli sme sa túto úlohu $\mathrm{v}$ teste ponechat', pretože naším zámerom nie je klasifikovat' žiakov známkou, ale zistit' úroveň pochopenia prírodovedných pojmov žiakmi, a tiež úroveň schopnosti používat' prírodovedné poznatky $\mathrm{k}$ riešeniu problémov $\mathrm{z}$ bežného života.

Obtiažnost' testových úloh (tab. 3) sme posudzovali podl'a výsledkov posttestu a určili podl'a vzorca ${ }^{4} \mathrm{Q}=100 . \mathrm{n}_{\mathrm{n}} / \mathrm{n}$. Index obtiažnosti $\mathrm{P}$ sme určili podl'a vzorca ${ }^{5} \mathrm{P}=100 . \mathrm{n}_{\mathrm{s}} / \mathrm{n}$.

Citlivost' testových úloh (tab. 4) d - do akej miery úloha rozlišuje medzi žiakmi s lepšími a horšími vedomost'ami - sme určili podl'a koeficientu $\mathrm{ULI}^{6} \mathrm{~d}=\mathrm{n}_{\mathrm{L}}-\mathrm{n}_{\mathrm{H}} / 0,5 \mathrm{~N}$

\section{Tabul'ka 4: Citlivost' úloh v didaktickom teste.}

\begin{tabular}{|l|c|c|c|c|c|c|c|c|}
\hline \multirow{2}{*}{ úloha } & \multicolumn{3}{|c|}{$\mathbf{1 + 2}$} & \multicolumn{3}{|c|}{$\mathbf{3}$} & \multicolumn{3}{|c|}{} & $\mathbf{5}$ \\
\cline { 2 - 10 } & $\begin{array}{c}\mathbf{1 a} \\
+\mathbf{2 a}\end{array}$ & $\begin{array}{c}\mathbf{1 b} \\
+\mathbf{2 b}\end{array}$ & $\begin{array}{c}\mathbf{1 c} \\
+\mathbf{2 c}\end{array}$ & & $\mathbf{4 a}$ & $\mathbf{4 b}$ & $\mathbf{4 c}$ & \\
\hline $\mathbf{n}_{\mathbf{L}}$ & 92 & 108 & 91 & 161 & 32 & 114 & 31 & 161 \\
\hline $\mathbf{n}_{\mathbf{H}}$ & 0 & 0 & 0 & 48 & 0 & 0 & 0 & 86 \\
\hline $\mathbf{N}$ & 321 & 321 & 321 & 321 & 321 & 321 & 321 & 321 \\
\hline $\mathbf{d}$ & 0,57 & 0,67 & 0,57 & 0,70 & $\mathbf{0 , 2 0}$ & 0,71 & $\mathbf{0 , 1 9}$ & 0,47 \\
\hline úloha & $\mathbf{6}$ & $\mathbf{7}$ & $\mathbf{8}$ & $\mathbf{9}$ & $\mathbf{1 0}$ & $\mathbf{1 1}$ & $\mathbf{1 2}$ & \\
\hline $\mathbf{n}_{\mathbf{L}}$ & 161 & 161 & 161 & 116 & 0 & 103 & 1 & \\
\hline $\mathbf{n}_{\mathbf{H}}$ & 110 & 27 & 69 & 0 & 0 & 0 & 0 & \\
\hline $\mathbf{N}$ & 321 & 321 & 321 & 321 & 321 & 321 & 321 & \\
\hline $\mathbf{d}$ & 0,32 & 0,83 & 0,57 & 0,72 & $\mathbf{0 , 0 0}$ & 0,64 & $\mathbf{0 , 0 1}$ & \\
\hline
\end{tabular}

Podl'a M. Chrásku (1999) sa pri koeficiente ULI vyžaduje, aby $d$ bol aspoň 0,25 (pri úlohách s $30<\mathrm{Q}<70$ ) a aspoň 0,15 (pri úlohách s $20<\mathrm{Q}<30$ alebo $70<\mathrm{Q}<80$ ). Túto požiadavku nesplńajú úlohy $4 \mathrm{a}, 4 \mathrm{c}, \quad 10$ a 12 , avšak $\mathrm{v}$ našom

\footnotetext{
${ }^{4}$ kde $n_{n}$ bol počet žiakov, ktorí odpovedali nesprávne, alebo neodpovedali (za vyriešenie úlohy im bol pridelený nulový počet bodov) a $n$ je celkový počet žiakov v testovanej skupine (Bernátová, R., 2003).

5 kde $n_{s}$ bol počet žiakov, ktorí odpovedali správne (za vyriešenie úlohy im bol pridelený maximálny počet bodov) a $n$ je celkový počet žiakov $\mathrm{v}$ testovanej skupine (Bernátová, R., 2003).

${ }^{6}$ kde $d$ je koeficient citlivosti ULI, $n_{L}$ je počet žiakov z lepšej skupiny, ktorí danú úlohu riešili správne, $n_{H}$ je počet žiakov zhoršej skupiny, ktorí úlohu vyriešili správne a $\mathrm{N}$ je celkový počet žiakov.
} 
didaktickom teste sú viaceré úlohy špecifické, pretože sa nezameriavajú len na diagnostikovanie vedomostí žiakov, ale najmä na zmenu prekonceptov a zist'ovanie schopností žiakov porozumiet prírodovedným pojmom a zákonitostiam.

Pri administrácii didaktického testu je potrebné zaistit' optimálne podmienky pre všetkých testovaných žiakov tak, aby každý žiak dostal vlastný pracovný list, do ktorého by vpísal, prípadne zakreslil odpovede. $\mathrm{Na}$ vypracovanie didaktického testu sa odporúča dat' žiakom celú vyučovaciu hodinu (cca 40 minút).

\section{Záver}

Z výskumu vyplynulo, že učitelia primárneho vzdelávania najmenej radi vyučujú témy orientované na techniku a neživú prírodu (Melicherčíková, D., Melicherčík, M., 1996). Z uvedeného dôvodu sme sa zamerali práve na problematické technicky orientované témy prírodovedného učiva, ktoré reprezentuje tematický celok Technika, technické objavy $\mathrm{v}$ predmete prírodoveda $\mathrm{v} 3$. ročníku základnej školy. Navrhovaný vstupný test umožňuje učitel'ovi poznat' prekoncepty žiaka, jeho predstavy o určitých fenoménoch, na ktoré môže v procese edukácie nadväzovat'. Pri vyhodnocovaní výsledkov výstupného testu sa potom nesústred'ujeme na porovnávanie žiakov medzi sebou, ani podl'a vopred určených kritérií, ale na individuálny pokrok vo výkone každého žiaka.

Uvedený didaktický test bol využitý v našom výskume (Krupová, I., 2008) pri porovnávaní efektivity konštruktivistickej a tradičnej koncepcie vyučovania prírodovedy $\mathrm{z}$ hl'adiska pokroku v kognitívnej úrovni žiaka. Z výsledkov výskumu vyplynulo, že navrhovaná koncepcia na konštruktivistických princípoch bola efektívnejšia zhl'adiska zvýšenia úrovne osvojenia pojmov a schopností riešit' reálne životné situácie s využívaním prírodovedných vedomostí, oproti tradičnej koncepcii vyučovania prírodovedy.

\section{Zoznam bibliografických odkazov}

[1] BERNÁTOVÁ, R. Didaktický test na 1. stupni základnej školy. Prešov : Rokus, 2003. ISBN 80-89055-25-7.

[2] CHRÁSKA, M. Didaktické testy. Brno : Paido, 1999. ISBN 80-85931-68-0.

[3] KRUPOVÁ, I. Uplatňovanie experimentálnej metódy v prírodovednom vzdelávaní na 1. stupni ZŠ. Dizertačná práca. B. Bystrica : PF UMB, 2008.

[4] LAPITKA, M. Tvorba a použitie didaktických testov. Bratisava : Štátny pedagogický ústav, 1996. ISBN 80-85756-28-5

[5] ĆÁP, J., MAREŠ, J. Psychologie pro učitele. Praha : Portál, 2001. ISBN 80-7178-463-X

[6] MELICHERČÍKOVÁ, D., MELICHERČÍK, M. Analýza výučby prírodovedy na 1 . stupni ZŠ.

In: Vysokoškolská príprava učitel'ov. 2. čast'. Banská Bystrica : PdF UMB, 1996. s. 365-371. ISBN 80-8055-020-4.

[7] NIEMIERKO, B. Taksonomia celów wychowania. In: Kwartalnik pedagogiczny, 1979, roč. 24 , č. 2, s. 67-78.

[8] Štátny vzdelávací program pre 1. stupeň základnej školy v Slovenskej republike. ISCED 1

- Primárne vzdelávanie. [online]. 30.06.2008. Dostupné na Internete: <http://www.minedu.sk /index.php?lang $=$ sk\&rootId $=2319>$.

PaedDr. Ivana Krupová, PhD.

Pedagogická fakulta Katolíckej univerzity

v Ružomberku, Inštitút Juraja Páleša v Levoči

Kláštorská 38, 05401 Levoča, SR

Tel: +421534699190

E-mail: ivana.krupova@ku.sk

Www pracoviska: www.pf.ku.s 